\title{
Correlation Between Salivary Anxiety Markers and Salivary Biochemical Markers in Children with Primary and Mixed Dentition
}

\author{
Süt ve Karışık Dişlenme Dönemindeki Çocuklarda Tükürük Anksiyete \\ Belirteçleri ve Tükürük Biyokimyasal Belirteçler Arasındaki Korelasyon
}

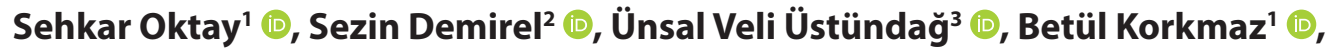

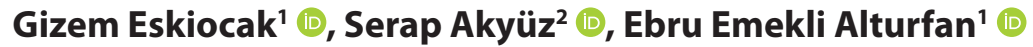

\author{
'Department of Basic Science Biochemistry, Marmara University School of Dentistry, İstanbul, Turkey \\ ${ }^{2}$ Department of Pediatric Dentistry, Marmara University School of Dentistry, Istanbul, Turkey \\ ${ }^{3}$ Department of Medical Biochemistry, Medipol University School of Medicine, İstanbul, Turkey
}

Cite this article as: Oktay S, Demirel S, Üstündağ ÜV, Korkmaz B, Eskiocak G, Akyüz S, et al. Correlation Between Salivary Anxiety Markers and Salivary Biochemical Markers in Children with Primary and Mixed Dentition. Experimed 2019; 9(3): 86-92.

\begin{abstract}
Objective: Anxiety due to the dentist and dental treatment is a problem encountered in many children. The aim of the present study is to determine salivary nitric oxide, lactoferrin, a-amylase and cortisol levels of children in primary and mixed dentition, and to evaluate their relation with stress due to dental treatment.

Material and Method: The study consisted of 50 children in primary and mixed dentition. The children were evaluated clinically and according to Frankl Behavior Rating Scale. Salivary flow rate was calculated, and nitric oxide, lactoferrin, a-amylase and cortisol levels were measured in saliva.

Results: $68 \%$ percent of the children were found to be negative according to the Frankl Behavior Rating Scale (category 2), and significantly decreased salivary flow rate was evident in these children when compared with children that were categorized as completely negative (category 1). The DMFT+dft index was 7.56 \pm 4.29 , and positive correlations were found between DMFT+dft indices and salivary nitric oxide, lactoferrin, cortisol and a-amylase levels $(p<0.05)$. These parameters were not different between genders. Positive correlations were found between salivary nitric oxide and $a$ amilase, cortisol and a amilase, cortisol and lactoferrin; and also between $a$-amilase and lactoferrin levels ( $p<0.05)$.
\end{abstract}

Conclusion: Salivary lactoferrin, a-amylase and cortisol may be suggested as important parameters of oral health.

Keywords: Anxiety, biochemical markers, saliva

\section{ÖZ}

Amaç: Diş hekimi ve diş tedavisine bağlı anksiyete birçok çocukta karşılaşılan bir sorundur. Bu çalışmanın amacı, süt ve karışık dişlenme dönemindeki çocuklarda tükürük nitrik oksit, laktoferrin, a-amilaz ve kortizol seviyelerini tespit etmek ve diş tedavisinden kaynaklanan stresle ilişkilerini değerlendirmektir.

Gereç ve Yöntem: Çalışma süt ve karışık dişlenme dönemindeki 50 çocuktan oluşmaktadır. Çocuklar klinik olarak ve Frankl Davranış Değerlendirme Ölçeğine göre değerlendirildi. Tükürük akış hızı hesaplandı ve tükürükte nitrik oksit, laktoferrin, a-amilaz ve kortizol seviyeleri ölçüldü.

Bulgular: Çocukların \%68'i Frankı Davranış Değerlendirme Ölçeğine göre negatif (Kategori 2) olarak bulundu ve bu çocuklarda, tamamen negatif olarak sınıflandırılan çocuklarla karşılaştırıldığında (Kategori 1) anlamlı derecede azalmış tükürük

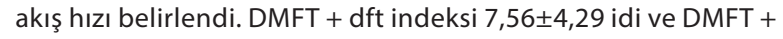
$\mathrm{dft}$ indeksleri ile tükrük nitrik oksit, laktoferrin, kortizol ve a-amilaz seviyeleri arasında pozitif korelasyon bulundu. Bu parametreler cinsiyetler arasında farklı değildi. Tükürük nitrik oksit ile amilaz, kortizol ve amilaz, kortizol ve laktoferrin ve ayrıca a-amilaz ve laktoferrin seviyeleri arasında pozitif korelasyon bulundu.

Sonuç: Tükürük laktoferrin, a-amilaz ve kortizol, ağız sağlığı ve anksiyete için önemli parametreler olarak önerilebilir.

Anahtar Kelimeler: Anksiyete, biyokimyasal belirteçler, tükürük 


\section{INTRODUCTION}

The importance of saliva as a non-invasive diagnostic fluid has increased in recent years. Accordingly, there is constantly increasing evidence supporting the use of saliva as a non-invasive tool for monitoring biomarkers in health and pathological human status (1). Saliva has unique functions to maintain dental health and in protecting against the harmful effects of microorganisms.

The composition of saliva consists of hormones, peptides, electrolytes, mucus, antibacterial compounds and different enzymes, as well as organic and inorganic compounds (2). Cortisol is one of the most important steroid hormones detectable in saliva (2). Lactoferrin and a-amylase, together with immunoglobulins, are the markers of mucosal immunity that are detectable in saliva. Lactoferrin is available in a variety of body fluids, including saliva. It is an iron-binding glycoprotein and protects the organism from infectious diseases by directly passing pathogens such as bacteria through the oral cavity viruses. Lactoferrin is present in the first line of defense in the face of pathogens in the mouth mucosa (3).

Nitric oxide (NO) is a short-lived gas that acts as a strong reactive radical, NO takes part in the defensive mechanisms of the oral cavity. Accordingly, antimicrobial effects of salivary NO metabolites, nitrates and nitrites, on protection against oral diseases, have been shown in recent years (4).

Cortisol, the main glucocorticoid of the organism, is an important component of the reactions called 'stress response', and can be reliably detected in saliva. Salivary cortisol is measured and used as a biomarker of psychological stress. On the other hand, salivary cortisol does not only reflect the hypothalamus-pituitary-adrenal axis (HPAA); different factors regulating HPAA reactivity such as the hippocampus, hypothalamus, pituitary and adrenals, as well as their modulators, receptors, or binding proteins, have all been reported to affect salivary cortisol measurements (5).

a-Amylase is an enzyme found in saliva that digests starch. Salivary a-amylase has also been shown to play a role in the digestive function, as well as the ability to fight bacteria in the mouth (6). In recent years, salivary a-amylase has been shown to be closely related to stress like cortisol, and has been suggested to increase in patients with chronic psychosocial stress, and may be used as a biomarker of chronic stress (7).

Dental anxiety, which is a major problem in pediatric dentistry, is more specific and important than general anxiety, and is a reaction to bad dental experiences. Dental fear and anxiety are problems that affect large populations, especially children (8). Avoidance of treatments and dental care may lead to serious consequences that adversely affect the oral health of the patients. It is important for dentists to identify the fearful patient group and patients who need special attention. Children express their anxiety in different ways, and dental anxiety in children should be assessed as early as possible (8).
Many methods have been developed for evaluating dental fear, in order to obtain the feelings hidden unconsciously. Detecting the anxiety level of patients and treating them accordingly, will have a positive effect on the patient's treatment experience and dental health (9). We hypothesized that biochemical parameters, such as cortisol, a-amylase, lactoferrin and nitric oxide, might be related to anxiety levels in children.

In this study, we aimed to evaluate the levels of salivary NO, lactoferrin, a- amylase and cortisol in children with primary and mixed dentition, and to assess the link between their behavior, evaluated according to the Frankl Behavior Rating Scale.

\section{MATERIAL AND METHOD}

\section{Subject Population}

The study consisted of 50 children (30 girls and 20 boys), in primary ( $n=25$, aged 5-7 years) and mixed ( $n=25$, aged 9- 11 years) dentition, who visited the Department of Pedodontics in Marmara University School of Dentistry. Children who did not have past systemic illness and undergoing any dental treatment, nor were taking drugs at least 6 months, were included the study.

\section{Calculation of DMFT+dft Index}

According to the clinical examination conducted at Marmara University School of Dentistry Pedodontic Clinic, for the permanent teeth of children; DMFT index was calculated by number of decayed, missing and filled permanent teeth, and dmft for number of decayed, missing and filled primary teeth. The children that were selected for this study at the Pedodontics clinic had not started treatment yet, had no systematic disease, and had not used antibiotics for the last month.

\section{Frankl Behavior Rating Scale}

Behavior assessment of the children was done using the Frankl Behavior Rating Scale (10).

Category 1: Absolutely negative: The child refuses treatment fearfully and shows a marked negative.

Category 2: Negative: The child is reluctant to accept treatment and there is a sign of negative attitude although it is not evident.

Category 3: Positive: The child accepts the treatment but there is a sign of being undecided. They listen to the dentist's message, but there are some suspicions.

Category 4: Absolutely positive: The child is in good agreement with the dentist and is involved in the dental procedures.

\section{Collection of Saliva}

Two hours before salivary collections, the children were requested to avoid eating food and drinking beverages. Whole saliva was collected by spitting into a tube. Saliva samples which were collected from children with dental examinations done by a pedodontist, were stored at $-20^{\circ} \mathrm{C}$ until analyses were made in the Basic Medical Science, Department of Biochemistry. 


\section{Salivary Flow Rate Measurement}

The salivary flow rate of the samples was calculated as saliva volume $(\mathrm{mL})$ collected per minute, using saliva collection volume and saliva collection time.

\section{Determination of Nitric Oxide}

Nitric oxide (NO) determination is based on reducing nitrate to nitrite by vanadium (III) chloride. In an acidic media, nitrite and sulfonylamide reacted with $\mathrm{N}$-(1-Naphtyl) ethylenediaminedihydrochloride, and complex diazonium compound was formed. The colored complex was measured at $540 \mathrm{~nm}$ by a spectrophotometer, and the results were expressed as $\mu \mathrm{mol} \mathrm{NO} / \mathrm{dL}$ (11).

\section{Determination of Lactoferrin}

The salivary lactoferrin level was measured by ELISA commercial kit, using lactoferrin- specific polyclonal antibody (Catalog no: EL 2011-1 AssayMax Human Lactoferrin ELISA KIT 96 Test Assaypro, St. Charles, MO, USA). The process followed the manufacturer's instructions. Briefly, standard and diluted samples were adsorbed in a polystyrene 96 well microplate and incubated for $2 \mathrm{~h}$ at $25^{\circ} \mathrm{C}$. After five-times repeated washing of wells with wash buffer, a biotinylated lactoferrin antibody was added to each well, and incubated for $1 \mathrm{~h}$.

After washing the microplate, $50 \mu$ l of streptavidin-peroxidase conjugate was added per well, and incubated for $30 \mathrm{~min}$. Subsequently, the third washing was applied. $50 \mu \mathrm{l}$ chromogenic substrate was used per well for detection, and incubated for 15 min. After $50 \mu$ l of stop solution was added, the plate was read at a wavelength of $450 \mathrm{~nm}$, using on a microplate reader.

\section{Determination of $a$-Amylase}

The a-amylase assay was performed using a commercial kit (Catalog no: 1-1902 Salivary Alpha-amylase kinetic Research, Salimetrics, LLC, USA). The process followed the manufacturer's instructions. Briefly, the plate reader was set to incubate at $37^{\circ} \mathrm{C}$. Controls and samples were adsorbed in 96 well microtiter plates. $320 \mu \mathrm{l}$ of the preheated $\left(37^{\circ} \mathrm{C}\right) \mathrm{a}$-Amylase Substrate was added to each well simultaneously, using a multichannel pipette.

Then, a timer was started immediately, and mixed (500 rpm) at $37^{\circ} \mathrm{C}$. The plate was transfered to the reader in time, the Optical Density (OD) was read at a wavelength of $405 \mathrm{~nm}$ exactly $1 \mathrm{~min}$.

After saving the $1 \mathrm{~min}$. OD readings, the plate was transfered to the reader again, the OD was read at a wavelength of $405 \mathrm{~nm}$ exactly 3 min., and saved.

Table 1. The results of the Frankl Behavior Scale

\begin{tabular}{lc}
\hline Category & $\%$ \\
\hline 1 & $10 \%(n=5)$ \\
\hline 2 & $68 \%(n=34)$ \\
\hline 3 & $22 \%(n=11)$ \\
\hline 4 & 0 \\
\hline
\end{tabular}

\section{Determination of Cortisol}

The Cortisol level in saliva was assessed using the commercial kit by EIA (Enzyme Immun Assay) method (Catalog No:1-3102 Salivary ER Cortisol EIA Kit Diagnostic, Salimetrics, State College, PA). All reagents were brought to room temperature and mixed before use. Standards and samples were adsorbed in 96 well microtiter plates, then $200 \mu$ l of diluted enzyme conjugate were added to each well. After, the plate was mixed on a plate rotator for $5 \mathrm{~min}$. at $500 \mathrm{rpm}$, and incubated at room temperature for $1 \mathrm{~h}$. After washing the plate 4 times, $200 \mu \mathrm{l}$ of TMB Substrate Solution were added to each well and mixed on a plate rotator for $5 \mathrm{~min}$. at $500 \mathrm{rpm}$, then, the plate was incubated in the dark (covered) at room temperature for $25 \mathrm{~min}$. After $50 \mu \mathrm{l}$ of stop solution were added, the plate was mixed on a plate rotator for $3 \mathrm{~min}$. at $500 \mathrm{rpm}$, and read at a wavelength of 450 $\mathrm{nm}$, using on a microplate reader.

\section{Statistical Analysis}

For all statistical analysis, GraphPad Prism 5.0 (GraphPad Software, San Diego, USA) was used. All data were expressed as mean \pm standard deviations (SD). The Kruskal Wallis test was used for the comparison of groups of data, followed by Dunn's multiple comparison tests. An unpaired, two tailed Student's T Test was used to compare two independent groups. Correlation analysis of clinical and laboratory data was performed by Spearman test. A value of $p<0.05$ was considered significant.

\section{RESULTS}

\section{Anxiety Results}

The results of the Frankl Behavior Rating Scale, which assessed fear situations of the children participating in the study before and during dental procedures, are shown in Table 1.

According to Frankl Behavior Rating Scale results, category 1 (absolutely negative) is $10 \%$, category 2 (negative) is $68 \%$, category 3 (positive) is $22 \%$ and category 4 (absolutely positive) is $0 \%$.

\section{Clinical and Biochemical Results}

The salivary flow rate and DMFT+dft index, NO, lactoferrin, a-amylase and cortisol values of the children participating in the study are given in Table 2. The children's salivary flow rate averaged $0.57 \pm 0.34 \mathrm{ml} / \mathrm{min}$ and the DMFT+dft index averaged $7.56 \pm 4.29$. The lowest value of these parameters was 0 , the highest were 1.5 and 17 , respectively. The average, lowest and highest levels of $\mathrm{NO}(\mu \mathrm{mol} / \mathrm{dL}): 193.0 \pm 55.09 ; 122.26$ and 286.78 respectively, lactoferrin $(\mathrm{ng} / \mathrm{mL}): 8.93 \pm 3.75 ; 3.73$ and 16.26 respectively, $\alpha$-amylase $(\mathrm{U} / \mathrm{mL}): 57.37 \pm 30.33 ; 22.30$ and 123.3 respectively, and cortisol (ug/dL): $0.64 \pm 0.22 ; 0.25$ and 0.99 respectively. There was no significant difference between girls and boys in terms of the parameters examined (Table 2 ).

The comparative results of salivary flow rate, DMFT-dft index and salivary nitric oxide, cortisol, a-amylase and lactoferrin values of children participating in the study, according to the Frankl Behavior Rating Scale, are given in Figure 1. Salivary flow rate decreased significantly in the Frankl 2 group compared to the Frankl 1 group $(p=0.004)$ (Figure 1a). 
Table 2. The salivary flow rate and DMFT+dft index, nitric oxide, lactoferrin, $a$-amylase and cortisol values of the children

\begin{tabular}{|c|c|c|c|c|c|}
\hline & $\begin{array}{c}\text { Average } \\
(n=50)\end{array}$ & $\begin{array}{l}\text { Lowest Level } \\
\qquad(n=50)\end{array}$ & $\begin{array}{l}\text { Highest Level } \\
\qquad(n=50)\end{array}$ & $\begin{array}{c}\text { Girls } \\
(n=30)\end{array}$ & $\begin{array}{l}\text { Boys } \\
(n=20)\end{array}$ \\
\hline Salivary flow rate (mL/min) & $0.57 \pm 0.34$ & 0 & 1.5 & $0.53 \pm 0.35$ & $0.63 \pm 0.34$ \\
\hline $\mathrm{DMFT}+\mathrm{dft}$ & $7.56 \pm 4.29$ & 0 & 17 & $7.87 \pm 4.31$ & $7.1 \pm 4.33$ \\
\hline Nitric oxide $(\mu \mathrm{mol} / \mathrm{dL})$ & $193.0 \pm 55.09$ & 122.26 & 286.78 & $191.0 \pm 57.73$ & $190.5 \pm 52.63$ \\
\hline Lactoferrin (ng/mL) & $8.93 \pm 3.75$ & 3.73 & 16.26 & $8.97 \pm 3.54$ & $8.87 \pm 4.16$ \\
\hline A-Amylase (U/mL) & $57.37 \pm 30.33$ & 22.30 & 123.3 & $58.05 \pm 32.62$ & $56.35 \pm 27.32$ \\
\hline Cortisol (ug/dL) & $0.64 \pm 0.22$ & 0.25 & 0.99 & $0.65 \pm 0.23$ & $0.62 \pm 0.21$ \\
\hline
\end{tabular}

Table 3. The results of correlation between the parameters examined

\begin{tabular}{|c|c|c|c|c|c|c|}
\hline & $\begin{array}{c}\text { Salivary flow rate } \\
\text { (mL/min) }\end{array}$ & DMFT-dft & $\begin{array}{l}\text { Nitric Oxide } \\
\text { ( } \mu \mathrm{mol} / \mathrm{dL})\end{array}$ & $\begin{array}{l}\text { Lactoferrin } \\
\text { (ng/mL) }\end{array}$ & $\begin{array}{c}\text { a-Amilase } \\
\text { (U/mL) }\end{array}$ & $\begin{array}{l}\text { Cortisol } \\
\text { (ug/dL) }\end{array}$ \\
\hline Salivary flow rate (mL/min) & & -0.106 & -0.066 & -0.094 & -0.163 & -0.035 \\
\hline DMFT-dft & -0.106 & & $0.902^{*}$ & $0.890^{*}$ & $0.884^{*}$ & $0.882^{*}$ \\
\hline Nitric Oxide ( $\mu \mathrm{mol} / \mathrm{dL})$ & -0.066 & $0.902^{*}$ & & 0.105 & $0.937^{*}$ & 0.204 \\
\hline Lactoferrin (ng/mL) & -0.094 & $0.890^{*}$ & 0.105 & & $0.820^{*}$ & $0.810^{*}$ \\
\hline a-Amilase $(\mathrm{U} / \mathrm{mL})$ & -0.163 & $0.884^{*}$ & $0.937^{*}$ & $0.820^{*}$ & & $0.849 *$ \\
\hline Cortisol (ug/dL) & -0.035 & $0.882^{*}$ & 0.204 & $0.810^{*}$ & $0.849 *$ & \\
\hline
\end{tabular}
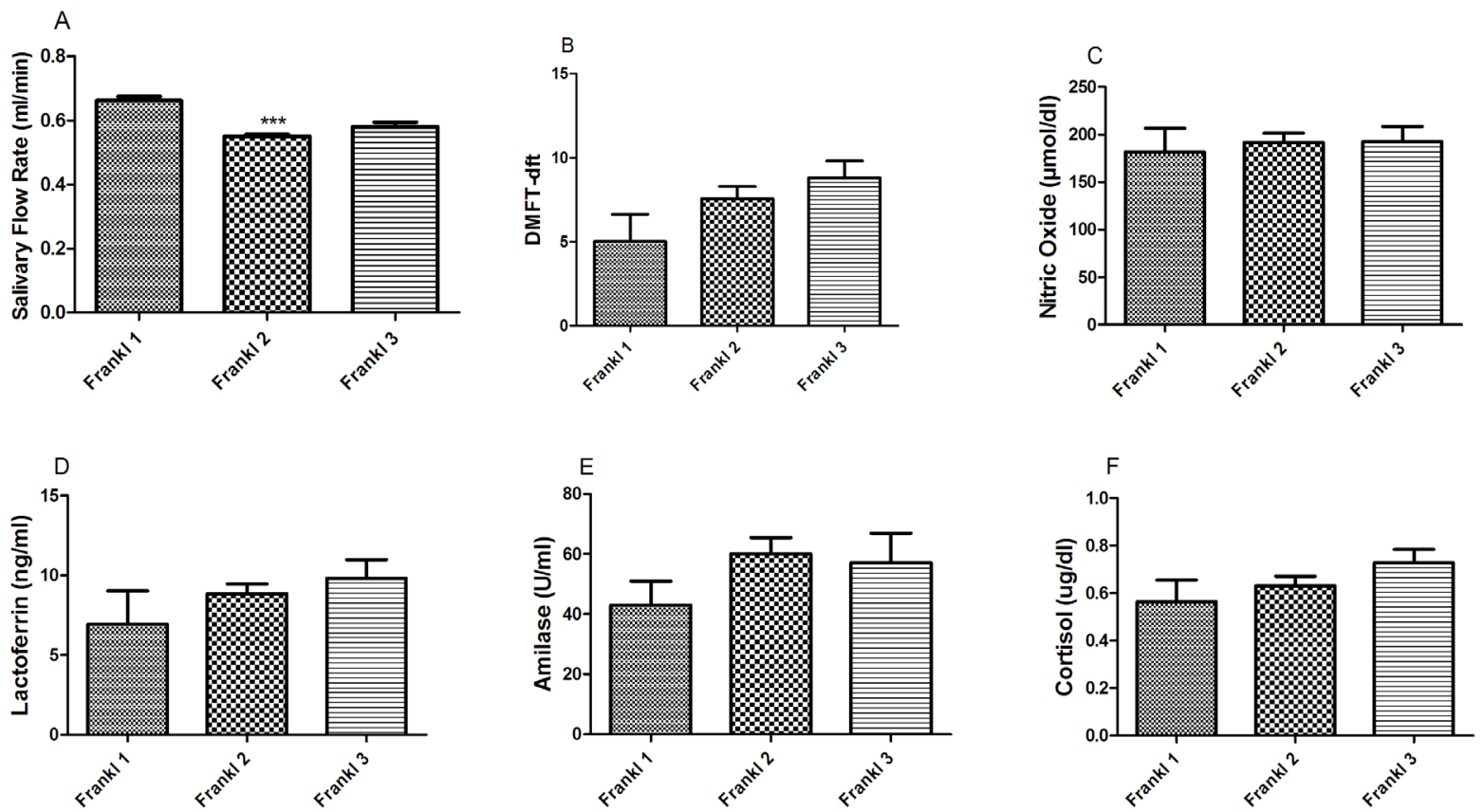

Figure 1. The comparative results of salivary flow rate, DMFT-dft index and salivary nitric oxide, lactoferrin, $a$-amylase and cortisol values of children according to the Frankl Behavior Rating Scale. ${ }^{* * *} p<0.01$ compared with the Frankl 1 group 
Except that, there was no significant difference between salivary parameters according to the Frankl 1, 2 and 3 scale. According to the Frankl Behavioral Rating Scale, there are no children in the definite positive group (Frankl 4), therefore, they are not included in the table. No significant difference was found between the groups when the examined parameters were classified for the Frankl Behavioral Rating Scale ( $p>0.05)$.

The results of correlation between the parameters examined are given in Table 3. There was a significant and positive correlation between DMFT+dft and salivary NO, lactoferrin, a-amylase and cortisol values $(r=0.902, r=0.890, r=0.884, r=0.882$, $p<0.001)$. In addition, there was a significant and positive correlation between salivary nitric oxide and a-amylase $(r=0.937$, $p<0.001)$, between cortisol and $a$-amylase $(r=0.884, p<0.001)$, between cortisol and lactoferrin $(r=0.810, p<0.001)$ and between $a$-amylase and lactoferrin $(r=0.820, p<0.001)$.

\section{DISCUSSION}

The results of the Frankl Behavior Rating Scale showed that the highest ratio of children is in category 2 , which means the majority of the children participating in the study (68\%) were reluctant to accept treatment and they were showing a sign of negative attitude, although not obvious.

This negative attitude may be related to the high DMFT+dft index and low salivary flow rate in this group, compared with the Frankl 1 group.

The results of our study also showed significant correlations between salivary NO, lactoferrin, cortisol, a-amylase levels and DMFT+dft indexes in children. It was shown that dental caries affect the immune system by causing inflammation, and lead to increase in various salivary biomarkers (12). The correlation between DMFT+dmft indices and salivary proteins in our study is consistent with this information. Salivary flow rate, NO, lactoferrin, a-amylase and cortisol levels were not different between girls and boys. As supported by the results of our study, anxiety due to the dentist and dental treatment is a common problem in children. As completely negative children would be expected to have more decreased salivary flow rate than negative children, the low number of children in category 1 and category 2 may have caused this finding. According to our literature search details, in the present study, the relationship between dental anxiety and salivary NO was investigated for the first time in the literature. There was no correlation between the results of the Frankl Behavioral Rating Scale and the salivary NO levels of the children participating in the study. The low number of patients participating in the study may be the reason for no significant correlation between saliva NO and anxiety. It was reported that NO is one of the agents involved in neurotransmitter dysfunction during anxiety and depression, and if anxiety and depression are an adaptation, NO may be involved during this adaptation (13). Also, it was shown that salivary NO levels of patients with periodontitis were higher than healthy individuals (14).
Because of individual differences in salivary secretion rates and gingival health, salivary antimicrobial factors show individual differences. There was a positive and strong correlation between saliva lactoferrin levels and the DMFT+dft index in our study. Felizardo et al. reported that $58.8 \%$ of the children did not have decay in their teeth and $63.3 \%$ of them had caries experience, and their lactoferrin concentration correlated positively with both DMFT and restored teeth number (15). Sikorska et al. (16) determined saliva lactoferrin levels in children aged 15 years, and reported that there was a significant relationship between caries surface index and saliva lactoferrin levels. As one of the defence factors in saliva, the direct bacteriostatic effect of lactoferrin, is not only depriving the most important elements necessary for bacteriological growth by binding the bacterium, but it is also achieved by destroying the outer membrane of the bacterium and building up NO in the macrophages (16).

It has been shown that a high a-amylase concentration in saliva affects oral health positively, and is associated with both physical and physiological stress conditions (6). In our study, it was found that salivary a-amylase correlates strongly with the DMFT-dft index and salivary NO. It was reported that a-amylase may play a role in plaque formation (17). Plaque formation and damage caused by bacteria may lead to increase NO in oral tissue. This relationship may be the cause of salivary a-amylase DMFT-dft index and NO correlation.

Collection of saliva is easier and less invasive than blood collection in children. The determination of salivary cortisol can provide great convenience, especially in field studies, large cohort studies and studies with children, due to stress-free collection and working conditions. Considering the correlation between saliva and blood, saliva can be used as an alternative to blood in free cortisol measurements (18).

In our study, cortisol levels in saliva samples collected from children participating in the study were examined to investigate the stress that the dental examination environment created. Sadi et al. (19) did not find any relationship between salivary cortisol levels and the patient's anxiety levels, also there was no correlation between salivary cortisol levels and those determined by the Frankl Behavior Rating Scale in this study. The lack of correlation between the Frankl Behavior Rating Scale and salivary cortisol and a-amylase may depend on the measurement method used to determine stress. The Frankl Behavior Rating Scale method is open to interpretation since it is observational. The grouping may vary according to the observer (20). Since children cannot express themselves as clearly as adults, the grouping of their current situation may vary.

A positive correlation between salivary cortisol levels and DMFT+dft indeces was found in our study. Rai et al. evaluated salivary cortisol levels in children with rampant caries (21).

These children reported acute pain and distress prior to dental treatment, and an increased level of cortisol was recorded in their saliva. Also, after dental treatment, a decreased level of sal- 
ivary cortisol, which was attributed to the absence of pain and reduced level of stress, was observed in their study. Additionally, Patil et al. (22) found a correlation between salivary cortisol and stress in dental procedure of healthy children undergoing routine dental procedures. Dental treatment is generally considered stressful and anxiety producing. These emotional states lead biochemical changes, such as elevation of salivary cortisol. Also, this may affect dental fear, and lead to the refusal of dental treatment, which may cause an increase in caries. Measurement of salivary cortisol is an accurate way of measuring adrenocortical function, and may be used as an index for stress (23).

Additionally, in the present study, a significant and positive correlation was found between salivary cortisol and a-amylase values. The role of salivary a-amylase in stress was investigated, and it was demonstrated that stress causes a significant increase in salivary a- amylase levels (24). Dental treatment itself can induce anxiety and fear in children, and these emotions cause significantly increased levels of salivary a-amylase immediately after dental treatment (25). Also salivary a-amylase was suggested as a marker of the autonomic nervous system response to stress in youth and adults (26). Unlike most salivary analytes that are actively transported or passively diffused into saliva from plasma, salivary a-amylase is locally produced in the oral mucosa of the salivary glands. The salivary glands are innervated by sympathetic and parasympathetic nerves, and salivary secretions from the glands arise in response to neurotransmitter activation. This suggests that salivary a-amylase may be a noninvasive marker of psychosocial stress autonomic activity (27).

A significant and positive correlation detected between a-amylase and lactoferrin is another important finding of our study. Lactoferrin is an important constituent of the innate immune system. Stressful conditions can affect the immune response, and stress may lead to physiobiochemical alterations in the constituents of saliva (28). Furthermore, dental caries may be suggested as being a triggering factor for a nonspecific immune response, and may lead to an increase in levels of these salivary proteins (29).

The limitation of the present study is the lack of children in category 4 according to the Frankl Behavior Rating Scale. Finding a study group as 'positive children' was not very applicable. It was very difficult to find enough children to make up this group because a 'completely positive group' means that the children loved the dentist treatment.

\section{CONCLUSION}

Our findings show the potential of salivary nitric oxide, lactoferrin, cortisol and a-amylase to reflect oral health. However, more studies are needed to prove the interaction of these parameters with dental anxiety in children.

Ethics Committee Approval: Ethics committee approval was received for this study from the Ethic Committee of Marmara University (dated 06.01.2012; Cert No. 10).
Informed Consent: Written informed consent was obtained from the parents of the patients who participated in this study.

Peer-review: Externally peer-reviewed.

Author Contributions: Concept -E.E.A, S.A.; Supervision - E.E.A, S.A.; Materials - S.O;S.D;U.V.U; B.K;G.E ; Data Collection and/or Processing S.O;S.D;U.V.U.; Analysis and/or Interpretation - S.O;S.D;U.V.U;E.E.A, S.A; Literature Search - S.O.; Writing - S.O; Critical Reviews - E.E.A, S.A.

Conflict of Interest: The authors have no conflict of interest to declare.

Financial Disclosure: The authors declared that this study has received no financial support.

Etik Komite Onayı: Bu çalışma için etik komite onayı Marmara Üniversitesi Etik Kurulu'ndan (tarih: 06.01.2012; Sert. No. 10) alınmıştır.

Hasta Onamı: Yazılı hasta onamı bu çalışmaya katılan hastaların ebeveynlerinden alınmıştır.

\section{Hakem Değerlendirmesi: Dış bağımsız.}

Yazar Katkıları: Yazar Katkıları: Fikir - E.E.A, S.A; Denetleme -E.E.A, S.A; Gereçler - S.O;S.D;U.V.U; B.K;G.E; Veri Toplanması ve/veya İşlemesi S.O;S.D;U.V.U.; Analiz ve/veya Yorum - S.O;S.D;U.V.U;E.E.A, S.A; Literatür Taraması -S.O; Yazan - S.O; Eleştirel İnceleme - E.E.A, S.A.

Çıkar Çatışması: Yazarlar çıkar çatışması bildirmemişlerdir.

Finansal Destek: Yazarlar bu çalışmada finansal destek almadıklarını beyan etmişlerdir.

\section{REFERENCES}

1. Berlutti F, Pilloni A, Pietropaoli M, Polimeni A, Valenti P. Lactoferrin and oral diseases: current status and perspective in periodontitis. Ann Stomatol 2011; 2: 10-8.

2. Chicharro JL, Lucía A, Pérez M, Vaquero AF, Ureña R. Saliva composition and exercise. Sports Med 1998; 26: 17-27. [CrossRef]

3. Legrand D, Pierce A, Elass E, Carpentier M, Mariller C, Mazurier J. Lactoferrin structure and functions. In: Bioactive components of milk. Springer, New York, NY, 2008. p. 163-94. [CrossRef]

4. Eagappan ARS, Rao VAP, Sujatha S, Senthil D, Sathiyajeeva J, Rajaraman G. Evaluation of salivary nitric oxide level in children with early childhood caries. Dent Res J 2016; 13: 338-41. [CrossRef]

5. Hellhammer DH, Wüst S, Kudielka BM. Salivary cortisol as a biomarker in stress research. Psychoneuroendocrinology 2009; 34: 163-71. [CrossRef]

6. Nater UM, Rohleder N. Salivary alpha-amylase as a non-invasive biomarker for the sympathetic nervous system: Current state of research. Psychoneuroendocrinology 2009; 34: 486-96. [CrossRef]

7. Vineetha R, Pai KM, Vengal M, Gopalakrishna K, Narayanakurup D. Usefulness of salivary alpha amylase as a biomarker of chronic stress and stress related oral mucosal changes - a pilot study. J Clin Exp Dent 2014; 6: 132-7. [CrossRef]

8. Seligman LD, Hovey JD, Chacon K, Ollendick TH. Dental anxiety: An understudied problem in youth, Clin Psychol Rev 2017; 55: 2540. [CrossRef]

9. Peretz B, Efrat J. Dental anxiety amoung young adolescent patients in Israel. Int J Paediatric Dent 2002; 10: 126-32. [CrossRef] 
10. FrankI SN. Should the parent remain with the child in the dental operatory? J Dent Child 1962; 29: 150-63.

11. Miranda KM, Espey MG, Wink DA. A rapid, simple spectrophotometric method for simultaneous detection of nitrate and nitrite. Nitric Oxide 2001; 5: 62-71. [CrossRef]

12. Monica M, Valad R, Stoica A. Analysis of salivary level of alpha-amylase as a risk factor for dental caries. Acta Medica Transilvanica March 2018; 23: 93-5.

13. Yildiz F, Erden BF, Ulak G, Utkan T, Gacar N. Antidepressant-like effect of 7-nitroindazole in the forced swimming test in rats. Psychopharmacology 2000; 149: 41-4. [CrossRef]

14. Inasu S, Thomas B, Kumari S, Ramesh A, Rao A. Evaluation of serum and salivary sialic acid and nitric oxide levels in chronic periodontitis patients. Int J Appl Dent Sci 2016; 2: 74-6.

15. Felizardo KR, Gonçalves RB, Schwarcz WD, Poli-Frederico RC, Maciel SM, de Andrade FB. An evaluation of the expression profiles of salivary proteins lactoferrin and lysozyme and their association with caries experience and activity. Rev Odonto Ciênc 2010; 25: 344-9. [CrossRef]

16. Sikorska MHJ, Mielnik-Blaszczak M, Kapec' E. The relationship between the levels of SigA, lactoferrin and proteinase inhibitor in saliva and permanent dentition caries in 15-year olds. Oral Microbiol Immunol 2001; 17: 272-6. [CrossRef]

17. Scannapieco FA, Torres G, Levine MJ. Salivary a-amylase: role in dental plaque and caries formation. Crit Rev Oral Biol Med 1993; 4: 301-7. [CrossRef]

18. Akyuz S, Pince $S$, Hekin N. Children's stress during a restorative dental treatment: assessment using salivary cortisol measurements. J Clin Pediatr Dent 1996; 20: 219-23.

19. Sadi $H$, Finkelman $M$, Rosenberg $M$. Salivary cortisol, salivary alpha amylase, and the dental anxiety scale. Anesth Prog 2013; 60: 4653. [CrossRef]

20. Aartman $\mathrm{IH}$, van Everdingen $\mathrm{T}$, Hoogstraten J, Schuurs AH. Appraisal of behavioral measurement techniques for assessing den- tal anxiety and fear in children: a review. J Psychopathol Behav Assess 1996; 18: 153-71. [CrossRef]

21. Rai K, Hegde A, Shetty S, Shetty S. Estimation of salivary cortisol in children with rampant caries. J Clin Pediatr Dent 2010; 34: 249-52. [CrossRef]

22. Patil SJ, Shah PP, Patil JA, Shigli A, Patil AT, Tamagond SB. Assessment of the changes in the stress-related salivary cortisol levels to the various dental procedures in children. J Indian Soc Pedod Prev Dent 2015; 33: 94-9. [CrossRef]

23. Nater UM, Rohleder N, Gaab J, Berger S, Jud A, Kirschbaum C, etal. Human salivary alpha-amylase reactivity in a psychosocial stress paradig. Int J Psychophysiol 2015; 55: 333-42. [CrossRef]

24. Rohleder N, Wolf JM, Maldonado EF, Kirschbau C. The psychosocial stress-induced increase in salivary alpha-amylase is independent of saliva flow rate. Psychophysiology 2006; 43: 645-52. [CrossRef]

25. Noorani H, Joshi HV, Shivaprakash P. Salivary alpha amylase as a noninvasive biomarker for dental fear and its correlation with behavior of children during dental treatment. Int J Clin Pediatr Dent 2014; 7: 19-23.

26. van Stegeren A, Rohleder N, Everaerd W, Wolf OT. Salivary alpha amylase as marker for adrenergic activity during stress: effect of betablockade. Psychoneuroendocrinology 2006; 31: 137-41. [CrossRef]

27. Tanaka Y, Ishitobi Y, Maruyama Y, Kawano A, Ando T, Okamoto S, et al. Salivary alphaamylase and cortisol responsiveness following electrical stimulation stress in major depressive disorder patients. Prog Neuropsychopharmacol Biol Psychiatry 2012; 36: 220-4.[CrossRef]

28. Lonnerdal B, lyer S. Lactoferrin: molecular structure and biological function. Annu Rev Nutr 1995; 15: 93-110. [CrossRef]

29. Felizardo KR, Goncalves RB, Schwarcz WD, Poli-Frederico RC, Maciel SM, de Andrade FB. An evaluation of the expression profiles of salivary proteins lactoferrin and lysozyme and their association with caries experience and activity. Rev Odonto Cienc 2010; 25: 344-9. [CrossRef] 